\title{
Okruchy lustra w zaułkach Miasteczka. O wspomnieniach Michała Głowińskiego
}

\author{
Shards of Mirror in the Backstreets of the Town. On Michał Głowiński’s \\ Recollections
}

Abstract: The author analyses Michał Głowiński's short story volumes Historia jednej topoli $i$ inne opowieści [The History of One Poplar and Other Stories] and Ktadka nad czasem [A Footbridge over Time] as well as a cycle of essays Widoczki z Miasteczka [Views from a Small Town] from Fabuty przerwane [Discontinued Plots] from the point of view of the way in which the writer constructs "little narratives" devoted to his home town. The context is provided by his literature studies works, which help consider questions important for both Głowiński the writer and Głowiński the literary theorist. Thus, the narrative strategies, the problem of mimesis and (re)constructing the past, the role of the social patterns of speaking and intertextual references, the shaping of space through portraying the characters and its symbolic ordering by the flaneur narrator, as well as the tension between the documentary and fiction, representation and trauma, and literary awareness and irreducible individuality are all examined in this light. The author of the essay also points out in what sense the difference between the realistic "mirror carried along a main road" and the "shattered mirror" used by Głowiński corresponds to the difference between "finding the time" and "darning the memory."

Keywords: Michał Głowiński, recollections, theory of literature, space, narrative strategies, memory, intertextuality

Streszczenie: Autorka analizuje zbiory opowiadań Historia jednej topoli i inne opowieści oraz Kładka nad czasem i cykl Widoczki z Miasteczka z Fabut przerwanych Michała Głowińskiego pod kątem tego, w jaki sposób konstruuje on „małe narracje” poświęcone rodzinnej miejscowości. Za kontekst służą jego prace literaturoznawcze, pomagające w rozważaniu zagadnień ważnych i dla Głowińskiego-pisarza, i teoretyka literatury. W tym świetle rozpatrywane są więc strategie narracyjne, problem mimetyzmu i (re)konstruowania przeszłości, rola społecznych wzorów mówienia oraz nawiązań intertekstualnych, charakterystyka przestrzeni poprzez portretowanie bohaterów i jej symboliczne porządkowanie przez narratora-flâneura, napięcia między dokumentem a fikcją, reprezentacją a traumą, świadomością literacką a nieredukowalną jednostkowością. Autorka wskazuje też, w jakim sensie różnica 
między realistycznym „zwierciadłem przechadzającym się po gościńcu” a „rozbitym lustrem”, którym operuje Głowiński, koresponduje z różnicą między „odnajdywaniem czasu” a „cerowaniem pamięci”.

Słowa kluczowe: Michał Głowiński, wspomnienia, teoria literatury, przestrzeń, strategie narracyjne, pamięć, intertekstualność

\section{Wprowadzenie}

Spośród twórczości literackiej Michała Głowińskiego interesują mnie tutaj zwłaszcza Historia jednej topoli i inne opowieści (2003), Ktadka nad czasem. Obrazki z Miasteczka (2006) oraz cykl Widoczki z Miasteczka z Fabut przerwanych $(2008)^{1}$. Na boku pozostawiam między innymi bilansujące życiorys autora Kręgi obcości czy zogniskowane na Holocauście Czarne sezony, chociaż piętno doświadczeń żydowskich odcisnęło się na wszystkich jego tekstach beletrystyczno-autobiograficznych ${ }^{2}$. Pomijam też najnowszą Carska filiżankę, dotyczącą głównie okresu okupacji i problemu homoseksualizmu. O selekcji materiału zadecydowały dwa czynniki. Po pierwsze, zamierzam poddać analizie to, jak Głowiński buduje narracje poświęcone rodzinnemu miastu, dlatego wybrałam utwory bliższe pamiętnikowi niż autobiografii, czyli ukierunkowane raczej na rzeczywistość zewnętrzną zamiast na ewolucję ,ja”3. Po drugie, on sam zaznacza, że o ile Czarne sezony są „całkowicie niefikcyjne”, o tyle nie można tak powiedzieć o trzech wymienionych zbiorach i Magdalence z razowego chleba $a^{4}$. Spróbuję wydobyć ten rys fikcjonalny, unaoczniając elementy konstrukcji, literackiej nadorganizacji i intertekstualności.

1 Zob. M. Głowiński, Historia jednej topoli i inne opowieści, Kraków 2003; tenże, Kładka nad czasem. Obrazki z Miasteczka, Kraków 2006; tenże, Fabuty przerwane. Mate szkice 19982007, Kraków 2008. Pozycje te cytowane są w artykule jako odpowiednio: (H), (K) i (F) z numerem strony.

2 Por. „Jeśli zaznało się Zagłady nawet w dzieciństwie, to nie można się od niej zdystansować. Naznacza ona na całe życie" (M. Głowiński, Carska filiżanka. Szesnaście opowieści, Warszawa 2016, s. 14); „podejmował on nieustanną decyzję opowiadania-się-za bądź odrzucania tego, co miało być wyznacznikiem jego żydowskiej tożsamości” (M. Modrzejewska-Świgulska, M.M. Bogusławski, Czy istnieje "profesjonalny" i "nieprofesjonalny” wymiar biografii? Rozważania na kanwie "Opowieści autobiograficznej” Michata Gtowińskiego. Refleksja rozpisana na dwa gtosy [w:] Biografie naukowe. Perspektywa transdyscyplinarna, red. M. Kafar, Łódź 2011, s. 131).

${ }^{3}$ Zob. na przykład R. Lubas-Bartoszyńska, Nowsze problemy teoretyczne pisania o sobie. Przyktad wypowiedzi autobiograficznych pisarzy polskich ostatnich dziesięcioleci, „Przestrzenie Teorii” 2006 , nr 6, s. 58. Notabene, w szkicu tym przywoływane są również tomy wspomnień Głowińskiego.

${ }^{4}$ Zob. "Czy pan jest nowoczesny?”. Z Michatem Gtowińskim rozmawia Ryszard Koziotek, „Świat i Słowo” 2005, nr 1, s. 51. Zob. też M. Głowiński, Magdalenka z razowego chleba, Kraków 2001 - pozycja ta cytowana jest jako (M) z numerem strony. 
Warto rozważyć, które komponenty składają się na reprezentację Miasteczka w owych tekstach, jak interferują w nich różne kategoryzacje świata (psychospołeczna, egzystencjalna i metafizyczna) ${ }^{5}$, na jakich zasadach „spotykają się pisarz i czytelnik, użytkownik języka polskiego i jego badacz, uczestnik historii i zawodowy historyk literatury" ${ }^{6}$, a także jak autor lokuje dzieło wobec odbiorcy ${ }^{7}$. Bardziej aniżeli na zawartości fabularnej skupię się na strategiach narracyjnych, rozpatrywanych w kontekście literaturoznawczych prac Głowińskiego, które pogłębiają rozumienie omawianych opowiadań. Zastrzega on, co prawda, że w trakcie pisania usiłował zapomnieć o wiedzy teoretycznej ${ }^{8}$; czy jednak ten konstytutywny element własnej umysłowości i biografii ${ }^{9}$ można po prostu wziąć w nawias?

\section{Opowieść jako dokument?}

Rzeczona wiedza nie pozwala autorowi przystąpić do prostodusznego wspominania i każe tłumaczyć się przed odbiorcami żywiącymi oczekiwania związane z jego profesją, stąd w Ktadce... Głowiński korzysta z retoryki wstępu, by podkreślić skromne ambicje swego przedsięwzięcia. Zarazem ma świadomość, że utwory literackie bywają odczytywane w kategoriach dokumentów ${ }^{10} \mathrm{i}$ że niektórzy spodziewają się po nim tego rodzaju tekstu. Rezultatem jest ambiwalencja $\mathrm{w}$ postawie narratora: $\mathrm{z}$ jednej strony odmawia on snutym opowieściom walorów historycznych, $\mathrm{z}$ drugiej strony przykłada wagę do nieledwie naukowej rzetelności relacji. W Historii... nadmienia, że w refleksjach nad tytułową topolą posiłkuje się „encyklopedycznym artykułem dendrologa" $(\mathrm{H}, 5)$, dodatkowo dla uwierzytelnienia osobistych uwag i reminiscencji przywołuje fotografie, prasę, nawet monografię miasta. O ułomkach lustra, do których przyrównuje własną pamięć, twierdzi, że rejestrują przejawy życia $(K, 6)$, co sugeruje wykaz stanu rzeczy; mianuje też siebie „małym kronikarzem” (K, 26), a przydawka wynikająca z toposu skromności i z fragmentaryczności opisów nie umniejsza zobowiązania do wierności faktom. Narrator napomina siebie, by nie taić spraw drażliwych, ponieważ

5 Zob. M. Głowiński, „Spotykam go codziennie...”. Bolestawa Leśmiana - trzy kategoryzacje świata [w:] tegoż, Zaświat przedstawiony. Szkice o poezji Bolestawa Leśmiana, Kraków 1998, s. 196.

${ }^{6}$ W. Browarny, W kręgu Gtowińskiego, „Odra” 2010, nr 12, s. 114. (Słowa te dotyczą Kręgów obcości).

7 Zob. M. Głowiński, Dzieło wobec odbiorcy. Szkice z komunikacji literackiej, Kraków 1998.

${ }^{8}$ Zob. „Moja ktadka wznoszona nad czasem różne ma wymiary...” - rozmowa z Michatem Gtowińskim, rozm. Ż. Nalewajk, K. Krowiranda, „Tekstualia” 2006, nr 4, s. 97.

9 Warto dodać, że autor Narracji literackich i nieliterackich wygłosił nawet odczyt o strukturalizmie jako doświadczeniu osobistym - zob. M. Głowiński, Kręgi obcości. Opowieść autobiograficzna, Kraków 2010, s. 494.

${ }_{10}$ Zob. tenże, Odbiór, konotacje, styl [w:] tegoż, Dzieto wobec odbiorcy..., dz. cyt., s. 115. 
straciłby wiarygodność, przede wszystkim zaś dąży do wytyczenia granic pewników - oddzielenia „odtwarzania” od konfabulacji, projekcji, fantazmatów, domysłów - szacuje więc prawdopodobieństwo zdarzeń oraz roztrząsa mechanizmy pamięci (na przykład „kiedy po latach rekonstruuję go [plac - K.S.] z tamtego okresu, ożywiam w postaci, w jakiej wówczas go postrzegałem" H, 22). Toteż nie tylko w odniesieniu do Kręgów obcości, ale i do narracji o Miasteczku adekwatna wydaje się opinia, że autor „konceptualizuje swoje doświadczenie tak, jakby spoglądał na swoje życie z oddalenia, (...) poprzez właściwy filologowi intelektualiście nawyk "strukturyzowania» przedmiotu" 11 .

\section{Przestrzenne tematy i wariacje}

Skrupulatność uwidacznia się szczególnie w charakterystyce przestrzeni: „wyciągam plan Miasteczka. Nie dlatego, że błądzę, po prostu chcę zobaczyć, jak ów obszar wydzielony przedstawia się na tle ogólnej geografii Miasteczka, jak przebiegają jego granice i jak sytuuje się wobec innych jego części” (K, 64-65). Chcąc wrysować frapujący go wyimek w ramy całości (można rzec: strukturalistycznie studiując zjawisko $\mathrm{w}$ świetle systemu), narrator polega zatem na precyzji mapy. Za istotniejsze podejście trzeba jednak uznać stylizację na „niespiesznego spacerowicza” $(K, 12)$ - czyli nie badacza gabinetowego, lecz flâneura - choć o ile pierwowzór tego drugiego stanowił figurę symptomatyczną dla wielkomiejskiego pędu, o tyle u Głowińskiego flâneur włóczy się po leniwej prowincji, nad „wąską i płytką (...), ospał[ą] rzeczk[a]” (K, 9-10). Ostatecznie mapa jawi się jako sztuczny ład, gdyż nieprzejrzyste, labiryntowe ${ }^{12}$ Miasteczko nie spełnia wymogów regularności, brak w nim także rynku, który porządkowałby plątaninę uliczek, „nie da się tu odnaleźć myśli urbanisty, jest odbicie żywiołu historii”" ${ }^{13}$. Pomimo to - albo raczej właśnie dlatego - w wypadku analizowanych narracji mamy do czynienia $\mathrm{z}$ indywidualnymi „wariacjami przestrzennymi”, czyli symbolicznym organizowaniem przestrzeni, zachodzącym w domenie języka ${ }^{14}$.

Nadawanie znaczeń rozpoczyna się od wyboru zdrobnienia (Miasteczko) i epitetów typu „skromne”, „zapewniające codzienną rutynę” (H, 94), będące (w odczuciu wuja z São Paolo) „beznadziejnym, skrajnie zapyziałym

11 A. Ubertowska, „Kręgi obcości”, podwójne wyjście. Projekt autobiograficzny Michata Gtowińskiego, „Teksty Drugie” 2011, nr 4, s. 201.

${ }_{12}$ Zob. M. Głowiński, Labirynt, przestrzeń obcości [w:] tegoż, Mity przebrane. Dionizos Narcyz - Prometeusz - Marchott - labirynt, Kraków 1990. Oczywiście labiryntowość Miasteczka potęguje się jeszcze w snach (K, 208-209).

13 [Lektor], Nad Utrata, ,Tygodnik Powszechny” 2006, nr 8, s. 21.

${ }_{14}$ Zob. M. Głowiński, Przestrzenne tematy i wariacje [w:] tegoż, Dzieto wobec odbiorcy..., dz. cyt., s. 260. 
zaściankiem” $(\mathrm{H}, 88)$. Obiekcje może budzić również unikanie nazwy Pruszków, aczkolwiek nawet bez sygnałów tożsamości narratora $\mathrm{z}$ autorem detale topograficzne (rzeka Utrata, stacja Kolei Wiedeńskiej, większe przedsiębiorstwa et cetera) pozwolityby zidentyfikować prototyp. Nie tylko w interpretowanych tu zbiorach Miasteczko konsekwentnie pisane jest wielką literą, co skutkuje przypowieściową uniwersalizacją treści, niemniej nie należy pochopnie przyjmować wypowiedzi Głowińskiego, jakoby akcja działa się wszędzie i nigdzie ${ }^{15}$. Z tym określonym miejscem czuje się on przecież głęboko związany, czego dowodem choćby przybranie przez niego w pierwszym wyznaniu autobiograficznym (w tomie Dzieci Holocaustu mówią z 1993 roku) pseudonimu Adam Pruszkowski. I mimo odżegnywania się od nostalgii rodem z tak zwanej prozy korzennej, mimo stwierdzenia narratora, że opuszczał Miasteczko prawie z ulgą $(H, 28)$, okazuje się, iż z odleglejszej perspektywy liczne punkty jego topografii nabrały nowych sensów.

Pomiędzy tymi punktami przemieszcza się flâneur, bez pośpiechu oprowadzając odbiorcę, a jednocześnie wtajemniczając go w swoją „biograficzną historię przestrzeni” ${ }^{16}$ - wyszczególnia bowiem przeważnie miejsca porzucone lub pozbawione pierwotnej funkcji, uważane za peryferyjne, nawet podejrzane. Przeto oprócz biblioteki, dworca, krótko istniejącego getta, Czarnej Ulicy czy taboru kolejowego odwiedza w retrospekcjach nędzne podwórka, zamarły cmentarz, sklep rzeźnika na obrzeżach. W Widoczkach z Miasteczka zatrzymuje się między innymi przy bóżnicy, przytułku dla upośledzonych dzieci, sklepikach z ciastkami, kamienicy zrośniętej z legendą miłosną, każdy zaś obiekt ewokuje osobną historię. Jak - wbrew stereotypowi strukturalisty - przekonuje narrator, zawsze „Chodziło o pojedyncze sztuki” (H, 9).

Koncentracja na konkrecie implikuje preferencję dla skali mikro, wobec której zawodzi obiektywizm mapy: „Jak słyszałem, jego imieniem nazwano jedną z uliczek. Zapewne jest tak mała, że nie udało mi się jej odnaleźć. Nie pomógł plan miasta" (F, 78). Narrator zawierza więc bardziej prywatnym obserwacjom i asocjacjom, w których topografia zostaje zarysowana niemal mimochodem. Koresponduje to ze spostrzeżeniem Głowińskiego-teoretyka, iż coś, „co w przestrzeni omawianej odznacza się wymiernością, w przestrzeni mówiącej może być giętkie, zmienne (...). Wymiary przestrzeni mówiącej (...) niekiedy wyłaniają się z kontekstu, gdzie indziej pozwala je określić sytuacja, w jakiej realizuje się wypowiedž” ${ }^{17}$. Za ilustrację niech posłuży cytat: „mieszkaliśmy wprawdzie nie przy samym dworcu, ale trasa od naszego domu na stację zajmowała nie więcej niż kwadrans, a jeśli szło się na skróty, przechodząc nad Utratą pod niewielkim wiaduktem kolejowym, trochę mniej" $(H, 61)$.

\footnotetext{
15 Zob. „Moja ktadka wznoszona nad czasem...”, dz. cyt., s. 98.

16 Zob. A. Madaliński, Pochwata fikcji, „Twórczość” 2006, nr 10, s. 130.

${ }_{17}$ M. Głowiński, Przestrzenne tematy i wariacje, dz. cyt., s. 259.
} 
Innym wariantem takiego "ukonkretniania en passant" byłyby metafory przestrzenne ułatwiające wizualizację wyobrażeń ${ }^{18}$.

\section{Nowomowa i miasteczkowe gadanie}

Pod tym kątem warto też spojrzeć na wymiar temporalny. Gros opowiadań odsyła do epoki stalinowskiej, choć Głowiński z rzadka wprowadza konkretyzację czasową (typu „wkrótce po kieleckim pogromie” [H, 16]). O ile w Magdalence... wprost wyraża stanowisko wobec ówczesnej ideologii, o tyle w innych zbiorach dystans w stosunku do propagandy na ogół przebija w ironicznych wzmiankach (,był niedościgniony w zwalczaniu wrogów socjalizmu i w sławieniu nadludzkiego geniuszu chorążego pokoju” [F, 84]). Warunki polityczne manifestują się w opowiadaniach Głowińskiego zwłaszcza przez sferę komunikacji, w czym słychać echo jego zainteresowań nowomową. Tezę, że „atakuje ona każdego mówiącego językiem polskim ze wszystkich stron, właściwie nie sposób jej nie ulegać” ${ }^{19}$, potwierdzałby przypadek kobiety, która nieświadomie powtarzała propagandowe slogany, przeświadczona, że są jej osobistymi słowami $(\mathrm{H}, 156)$. Z kolei konflikt między zwyczajami mieszkańców a narzucanymi wzorami kulturowymi egzemplifikuje opisywaną przez autora Peereliady walkę paradygmatów symbolicznych ${ }^{20}$, tyle że - poniekąd w sprzeczności z powyższą diagnozą - badacz uwypukla siłę oporu, któremu sprzyjało zakotwiczenie tradycyjnych symboli właśnie w języku.

Stanowi to niebagatelne pole odniesienia, ponieważ narrator ochoczo odwołuje się do językowego obrazu świata ludności Miasteczka. „Dzieło literackie nie może "naśladować« świata, może naśladować jedynie sposoby mówienia o świecie"21 - przypomina Głowiński i nie ma na myśli tylko wypowiedzi literackich, lecz wszelkie usankcjonowane społecznie, osadzone w kontekście pragmatycznym ${ }^{22}$. Takie socjolingwistyczne nastawienie dochodzi do głosu na przykład w wyjaśnieniu: „Pozostanę przy tej nazwie, choć wiem, że jest błędna (...). A więc była to akacja, skoro tak o niej mówiono" $(\mathrm{H}, 8)$. Ponadto, idąc w ślad za narratologami, którzy akcentowali obecność fabuł w mowie potocznej ${ }^{23}$,

18 Zob. tamże, s. 255-261.

19 M. Głowiński, Nowomowa [w:] Antropologia stowa. Zagadnienia i wybór tekstów, wstęp, red. G. Godlewski, Warszawa 2003, s. 600.

20 Zob. tenże, Polska literatura wspótczesna i paradygmaty symboliczne (1945-1995) [w:] tegoż, Dzień Ulissesa i inne szkice na tematy niemitologiczne, Kraków 2000, s. 7-27.

21 Tenże, Poetyka a socjolingwistyka [w:] tegoż, Narracje literackie $i$ nieliterackie, Kraków 1997 , s. 246.

22 Zob. tenże, Mimesis językowa w wypowiedzi literackiej [w:] tegoż, Narracje literackie..., dz. cyt., s. 8 .

${ }_{23}$ Zob. tenże, Od metod zewnętrznych i wewnętrznych do komunikacji literackiej [w:] tegoż, Dzieto wobec odbiorcy..., dz. cyt., s. 21. 
autor czerpie z lokalnych podań i „wieści gminnej” („Andzia Przysmak żyje przecież w słowie, opowiadać można o wszystkich, także przeto o tych, co zrodzeni z plotek i z konceptów, z imaginacji [...]” [K, 26]). Świadom konwencjonalności aktu opowiadania stylizuje narratora na gawędziarza, niejednokrotnie otaczającego bohaterów aurą baśniowości. Oni również dopełniają charakterystykę przestrzeni, gdyż takie indywidua, jak Głupi Zdzisio, Siwek, lekarz zwany „Penicylinką”, „tajemniczy major Bieżancew”, młody meloman ze skrzypcami, ksiądz, który został znanym poetą, baba sprzedająca jajka i gadająca o „pydyraście” - nadają Miasteczku koloryt lokalny, współtworzą jego „stały ludzki pejzaż” (F, 78); zresztą przy okazji szkicowania owych postaci Głowiński ukazuje topograficzne i historyczne realia miasta.

\section{Literatura a nos Andzi Przysmak}

Tym samym „kładka nad czasem” ulega, można powiedzieć, przeistoczeniu w „kładki, na których spotykają się ludzie różnych czasów”, zazwyczaj przelotnie wydobyci z mroku, jakby oświetlono ich reflektorem lub raczej „zajączkiem" z lusterka wspomnień. Niektórzy pojawiają się na scenie Miasteczka tylko na pewien okres i narrator nie potrafi ustalić, skąd przywędrowali ani jak wyglądały ich dalsze losy. Portrety części z nich ujęte są w ramy scenek rodzajowych, humorystycznych ramotek; zasadniczo wszakże nad anegdotą dominuje figura braku i tonacja zadumy nad tymi, którzy albo nie przetrwali wojny, albo przeżyli, lecz „osmaleni”, albo egzystują jak pani Janina pielęgnująca trzy domniemane groby córki. Miejscowa rzeka nabiera eksplicytnych znamion symbolu: Miasteczko i jego historię przecina bowiem Utrata, przede wszystkim spowodowana przez Zagładę. „Prawdopodobnie losy były typowe - rekonstruuje Głowiński dzieje jednej z rodzin - krótkotrwałe getto w Pruszkowie, getto w Warszawie, Treblinka. Tu nic innego nie mogło pewnie się zdarzyć" ${ }^{24}$. Ofiary masowej zbrodni obligują żyjących do świadectwa w tym sensie Ktadka... stanowi literackie epitafium dla zamordowanej zbiorowości ${ }^{25}$ - ale obowiązek udokumentowania dotyczy nie tylko istnień, które pochłonął Holocaust. Każdej postaci narrator próbuje na swój sposób oddać sprawiedliwość, gdyż mógłby powiedzieć o nich to, co o tytułowej topoli, własnej axis mundi: że pamięta ją słabiej niż puste miejsce po niej (H, 9). W Magdalence... uwiecznia matematyczkę, która zapisała się w jego wspomnieniach ze względu na ciągłe powracanie w reminiscencjach do wywózki na Syberię, i oświadcza, że dopiero on po kilku dekadach „wyciaga ją z królestwa niepamięci” (M, 15). Dysponuje nader skąpymi danymi, lecz chociaż

24 „Moja kładka wznoszona nad czasem...”, dz. cyt., s. 92.

${ }_{25}$ Nawet podtytuł Obrazki z Miasteczka stanowi aluzję do Obrazków z wystawy skomponowanych przez Modesta Musorgskiego po śmierci przyjaciela - zob. tamże, s. 89. 
deklaruje w duchu strukturalizmu: „Przyczyny nie mają dla mnie większego znaczenia, ważna jest sama zmiana" $(\mathrm{H}, 29-30)$, to jednak tych przyczyn docieka, a luki wypełnia domysłami i literaturą - jedynym narzędziem przedłużania istnienia tamtych ludzi i czynienia go kompletnym.

Skuteczności owej metody dowodziłyby rozważania o pewnym pracowniku fabryki fajansów, odnotowanym w monografii Miasteczka. Autor opracowania znał tylko jego nazwisko, autor opowiadań - losy oraz imię Harry, które kojarzył z protagonistą Wilka stepowego, zwłaszcza że oba nazwiska (Heller i Rubin) brzmiały mu książkowo $(\mathrm{H}, 78)$. Pomimo to metoda taka wydaje się kontrowersyjna. W jednym z artykułów Głowiński przyrównuje literaturę do króla Midasa ${ }^{26}$ (przemienia ona wszystko, z czym się zetknie, w literackość), a w omawianych tomikach nie kryje, że pamięć jest uwikłana w artystyczno-narracyjne konwencje - raz po raz odsłania wzorce genologiczne swoich narracji, operuje intertekstualnością ujawnioną, cytatami wyodrębnionymi („chodził tak, jakby "nie mógł iść inaczej, jak tylko w podskokach«” [F, 82]), głównie zaś kryptocytatami. Aluzji nie powinno się jednak - przestrzega uznawać za ornament czy bezcelową zagadkę dla czytelnika, lecz pytać o ich miejsce i funkcje w strukturze i semantyce utworu ${ }^{27}$. Gdy więc narrator cytuje: „Pamiętam, chociaż byłem wtenczas małe dziecię...” (H, 5), daje wyraz świadomości, że wspominanie stanowi motyw ogromnie obciążony retorycznie. Niekiedy wprost zestawia swych bohaterów z wykreowanymi na kartach powieści („Znowu przywołam analogię literacką: nie wiem, czy była poholokaustową panią Bovary [...]” [H, 106]), eksponując to, że obcujemy ze światem przedstawionym, a życie naśladuje literaturę, jego koleje wpasowują się w pospolite schematy fabularne.

W tym świetle problematyczne może być oddanie sprawiedliwości jednostkom, niemniej warto mieć na uwadze, co Głowiński pisał o roli wyjątkowości w literaturze ${ }^{28}$. Podobnie jak strukturalista nie bada wyłącznie reguł systemowych, ale przechodzi do rozpatrywania konkretnych realizacji i znaczeñ $^{29}$, narrator pragnie uchwycić postacie w ich unikatowości. Tu zbliża się do hermeneutyki ${ }^{30}$, a zarazem do psychologii rozumiejącej, wrażliwej na indywidualny ogląd świata: „Casus tej starej kobiety, poszukującej parasolki z rączką z czerwonej masy, nie jest dla mnie przypadkiem w sensie medycznym, stanowi pewną ludzką sytuację, którą chciałbym zrozumieć” $(\mathrm{H}, 145)$. O będącej tematem reportażu desperackiej obronie przydomowego drzewa nadmienia,

${ }^{26}$ Zob. M. Głowiński, O powieści w pierwszej osobie [w:] tegoż, Gry powieściowe. Szkice z teorii $i$ historii form narracyjnych, Warszawa 1973, s. 68.

27 Zob. tenże, O intertekstualności, „Pamiętnik Literacki” 1986, z. 4, s. 89-90.

${ }_{28}$ Zob. tenże, Literatura a nos Kleopatry [w:] tegoż, Dzieto wobec odbiorcy..., dz. cyt., s. $271-283$.

${ }^{29}$ Zob. tenże, Nauka o literaturze wśród innych dyscyplin [w:] tegoż, Monolog wewnętrzny Telimeny i inne szkice, Kraków 2007, s. 10.

30 Sam autor zresztą przekonuje, że ich niektóre nurty są zbieżne - zob. tamże, s. 12-13. 
że „znawca form gazetowej prozy” $(\mathrm{H}, 25)$ nazwałby ją fait divers, lecz sam Głowiński dostrzega w niej coś więcej niż sensacyjkę - i nic dziwnego, skoro jako badacz odkrywa egzystencjalne zaplecze poetyckich fait divers Mirona Białoszewskiego ${ }^{31}$.

\section{Symbole i symbolika}

Czy jednak nie czyha tutaj zagrożenie odwrotne: przekuwanie tego, co prozaiczne, w podniosłą parabolę? Jeśli według narratora rodzaj topoli nie ma znaczenia, „bo topola jest topolą, jest topolą, jest topolą...” (H, 5), to przez aluzję do sławnego zdania Gertrude Stein wskazuje on, że tym razem nie chodzi o świadomość potoczną, która obywa się bez wiedzy botanicznej, ale o krytyczną świadomość literacką. Stąd akcentowanie dystansu wobec banalnych sensów naddanych („nie dopatruję się w praniu znaku wielkiego oczyszczenia” $[\mathrm{H}, 223])$, zwłaszcza wobec traktowania drzewa jako symbolu trwania pomimo hekatomby ${ }^{32}$. Niemniej Głowiński nie rezygnuje z poszukiwań - by rzec za Czesławem Miłoszem - „podszewki (wspominanego) świata”33, pewien, że literatura, uczestnicząc $w$ uniwersum symbolicznym, może je przeobrażać i wzbogacać. Jak podkreśla: „Przestrzeń zwerbalizowana nie jest na ogół przestrzenią bezinteresowną. Mówiąc o niej (...), zawsze mogę mówić o czym innym, co należy do świata wyobrażeń moralnych, ideologicznych, religijnych itp." ${ }^{34}$. Przestrzeń Miasteczka zostaje skorelowana z dramatyczną dolą społeczności żydowskiej, co ilustrują stopniowa dewastacja domu oraz placu, na którym bawiła się Żydówka z córką endeków, czy zarastający kirkut, wkrótce obcy pozostałym mieszkańcom niczym nekropolie Etrusków. Symbolem staje się też księga rachunkowa dziadka-przedsiębiorcy, usiłującego odzyskać po wojnie śladowe długi - niejako przynajmniej w mikroskali przywrócić sprawiedliwość - lecz w oczach dawnych sąsiadów starszy mężczyzna przypomina już niepożądaną zjawę. On i oni personifikowaliby opozycję restauracji i rewolucji ${ }^{35}$, gdyż dla dziadka ostatecznie upada wówczas nadzieja na ład.

„Symboliczne są przedmioty lub wydarzenia odczuwane jako ważniejsze, niżby wyjaśnić to mógł bezpośrednio rozsądek" ${ }^{36}$ - powtarza Głowiński za

31 Zob. M. Głowiński, Mate narracje Mirona Biatoszewskiego, „Teksty” 1972, nr 6, s. 16-22.

32 „Takie ujęcie sprawy byłoby zbyt łatwe i zapewne graniczyło z tandetą: wokół śmierć, zgroza, wyniszczenie, a drzewo, traktowane emblematycznie, spokojnie sobie rośnie, (...) świadcząc, że nawet w momentach najstraszniejszego kryzysu trwają takie lub inne formy życia. (...) dobry stan drzewa nie sprawił, że czyjakolwiek śmierć stała się lżejsza - i nabrała sensu” (H, 20).

33 Zob. C. Miłosz, Sens [w:] tegoż, Wiersze, t. 5, Kraków 2009, s. 285.

${ }^{34}$ M. Głowiński, Przestrzenne tematy i wariacje, dz. cyt., s. 253.

${ }_{35}$ Zob. tenże, Literatura wobec symboliki [w:] tegoż, Monolog wewnętrzny Telimeny..., dz. cyt., s. 57.

36 Tamże, s. 48. 
Wystanem H. Audenem, swoje narracje zaś oplata właśnie wokół obiektywnie nieistotnych miejsc i zjawisk, medytując nad ich nieoczywistą wymową. Pisze:

Nasze Miasteczko nie ma szans, by stać się mazowieckim odpowiednikiem Pompei, a wraz z nim nie ma szans ów drewniak, zapadający się z biegiem czasu. Ale pytanie mnie dręczy: jakim byłby świadectwem życia, gdyby się zdarzyło, że wchłonęła go ziemia, ocalając takie lub inne jego cząstki? $(\mathrm{H}, 18)$.

Narratora-strukturalistę niepokoi niezborność cząstek, niemożność uzyskania kompletnego obrazu, mimo to snuje „małe narracje”, równie wielowarstwowe jak te, które Głowiński-badacz omawia w szkicu o Białoszewskim ${ }^{37}$. Przecież - zauważa à propos rezultatów transformacji ustrojowej autor Kręgów obcości - „wielkie ujawnia się w tym także, co może się wydawać małe” ${ }^{38}$. O Bolesławie Leśmianie z kolei stwierdza: „Obraca się on wśród drobnych realiów, jakże konkretnych w swej materialności - i w kosmosie" ${ }^{39}$. Narrator opisuje zatem błahe-niebłahe okoliczności życia mieszkańców Miasteczka, a służąc ich pamięci, służy jednocześnie własnej przeszłości, reinterpretuje ją i rewaloryzuje, więcej: „lepi siebie” z cudzych życiorysów i cudzej mowy, przekazów oralnych oraz tekstów literackich. Opowiadania, publikowane zrazu w czasopismach, tworzą całość nie tylko w formie książek, ale także z perspektywy Kręgów obcości, jak bowiem zauważają krytycy, przed tym opus magnum Głowiński „musiał najpierw mikrologicznie zmierzyć się z okruchami, strzępami i strupami pamięci autobiograficznej”“ „Zmierzyć się”, gdyż możliwość zsyntetyzowania odrębnych zdarzeń i wrażeń - mogącego objawić „pewien ogólny sens, ten, jaki podmiot odkrywa w swojej biografii”¹ - pozostaje problematyczna.

\section{„A wszystkiemu się przyglądałem”?}

Warto przytoczyć jeszcze jeden cytat ze studium o „elegijnym schemacie autobiograficznym" w twórczości Leśmiana, ponieważ ma on zastosowanie także do narracji autora Ktadki...:

37 Zob. tenże, Mate narracje Mirona Biatoszewskiego, dz. cyt., s. 9-28.

${ }^{38}$ Tenże, Kręgi obcości..., dz. cyt., s. 477.

39 Tenże, „Spotykam go codziennie...”, dz. cyt., s. 197.

${ }^{40}$ K. Kuczyńska-Koschany, Gtowiński: tożsamość proza (od początku), „Poznańskie Studia Polonistyczne" 2003, Seria Literacka, t. 22, s. 126.

${ }^{41}$ M. Głowiński, Elegie autobiograficzne Leśmiana [w:] tegoż, Zaświat przedstawiony..., dz. cyt., s. 261-262.

${ }_{42}$ Zob. tenże, "A wszystkiemu się przygladatem”. O opowiadaniach Janusza Odroważa-Pieniążka [w:] tegoż, Rozmaitości interpretacyjne. Trzydzieści szkiców, Warszawa 2014, s. 121127. Notabene, także inne śródtytuły (prócz ostatniego) powtarzają lub parafrazują tytuły szkiców bohatera artykułu. 
Elegie odznaczają się trzema podstawowymi właściwościami: 1. podkreślają moment poznawczy $\mathrm{w}$ ujęciach przeszłości i w konsekwencji tematyzują sam akt wspominania; 2 . wprowadzają silnie uwydatniane przeciwstawienie: dawniej-dzisiaj; 3. usamodzielniają i na swój sposób reifikują to, co należy do sfery określanej słowem „dawniej”³.

Głowiński uwypukla tutaj rolę rekonstrukcyjnych czynności podmiotu i również w elegijnych „obrazkach z Miasteczka” opowiadanie o przeszłości prezentuje jako wyzwanie intelektualne i literackie. Nawiązując do jego rozpoznania dotyczącego nouveau roman („Kwestią zasadniczą staje się więc krytyka powieściowego rozumu, krytyka dokonywana wewnątrz samej powieści i środkami uważanymi za najbardziej dla niej charakterystyczne" ${ }^{44}$ ), można odczytać owe obrazki jako „krytykę wspominającego rozumu”. Swoje retrospekcje traktuje autor niczym rzeczywistość tekstową, przekład przednarracyjnej struktury doświadczenia na formę i semantykę narracji ${ }^{45}$. Służą temu passusy dyskursywne i metaliterackie, na przykład tryb warunkowy i historie kontrfaktyczne, demaskowanie ograniczeń konwencji, apostrofy do czytelnika i projektowanie jego roli czy wejście in medias res w sytuację „powrotu do przeszłości”, który opatrzony jest licznymi wątpliwościami, choćby dlatego, że narrator nie przyjmuje „niewinnej” optyki dziecięcej, zwalniającej od konieczności wyjaśnień.

Także poza partiami autotematycznymi nie udaje on „zanurzenia”, raczej wciąż przemieszcza się po tytułowej kładce. Trudno zatem się w pełni zgodzić z opinią, że „precyzyjnie porusza się we własnej przeszłości” ${ }^{46}$, aczkolwiek mógłby to sugerować elegancki, powściagliwy, a zarazem finezyjny ję$\mathrm{zyk}^{47}$. Brak ekspresywności i postawa świadka nie oznaczają braku emocji, gdyż - jak przyznaje autor - trudno patrzeć chłodno z perspektywy historyka na przeżycia osobiste i pokoleniowe ${ }^{48}$. Trafniejsza wydaje się przeto konstatacja, że „Chłopiec spoglądający przez okno na życie pruszkowskiej ulicy był oczywiście Michałem Głowińskim, jednak Głowiński-narrator nie kryje istnienia jakiejś przepaści, która rozdziela te dwa wcielenia jego własnej osoby” ${ }^{49}$.

43 Tenże, Elegie autobiograficzne Leśmiana, dz. cyt., s. 250.

${ }_{44}$ Tenże, Powieść jako metodologia powieści [w:] W kręgu zagadnień teorii powieści, red. J. Sławiński, Wrocław 1967, s. 81.

${ }^{45}$ Zob. na przykład P. Ricoeur, Czas i opowieść, t. 1: Intryga i historyczna opowieść, tłum. M. Frankiewicz, Kraków 2008, s. 83-85.

${ }^{46}$ M. Broda, W cieniu pamięci: byt plac, byt dom, byta topola..., „Kwartalnik Artystyczny” 2003, nr 4, s. 151.

47 Zob. na przykład K. Jakowska, O narracjach autobiograficznych Michata Gtowińskiego i Andy Rottenberg, „Białostockie Studia Literaturoznawcze” 2010, t. 1, s. 52-53.

${ }_{48}$ Zob. M. Głowiński, My z lat trzydziestych. (Rozważania aż nadto subiektywne) [w:] tegoż, Dzień Ulissesa..., dz. cyt., s. 164.

${ }^{49}$ W. Lewandowski, Z diabtem po Miasteczku, „Kwartalnik Artystyczny” 2006, nr 2, s. 242. 
Obrazy widziane rozmijają się z zapamiętanymi, bo chociaż Miasteczko nie należy do kresowych ojczyzn utraconych, nieustannie przypomina o Zagładzie, ale też o prawdzie, że wszyscy jesteśmy wygnańcami. Fundamentalnym problemem okazuje się bowiem czas rozdarty - nie tylko „w mentalnym świecie pani Anieli (...) utracił [on - K.S.] swą linearność, jego segmenty nie następowały po sobie (...)" (H, 145-146). Wskutek Holocaustu oraz gwałtownych przemian politycznych i społeczno-kulturowych zamiast realistycznego „Zwierciadła przechadzającego się po gościńcu” napotkać można jedynie lustro rozbite, niewyraźne, odbijające wycinki różnych zaułków, toteż Głowiński „nie rości sobie pretensji do wykreowania holistycznej wizji przeszłości, nie próbuje nakreślić pełnej panoramy miejsca (...). Interesują go raczej fragmenty rzeczywistości, jej odblaski, które pozostają w pamięci (...)" ${ }^{\text {50 }}$. Nasuwa się tu analogia do Lacanowskich koncepcji „stadium zwierciadła" ${ }^{1}$, a także trzech porządków - Realnego, Wyobrażonego i Symbolicznego. Wierne, gładkie lustro klasycznej powieści dałoby się porównać z ową fazą, w której dziecko uchwytuje swój całościowy wizerunek w odbiciu i zaczyna się z nim identyfikować. Natomiast w szczątkach potłuczonego lustra wolno upatrywać, po pierwsze, przejścia od Wyobrażonego do Symbolicznego, czyli do alienującego języka (uwikłania w konwencje narracyjne, mówienia zawsze „cudzym”, nieidiomatycznym głosem $)^{52}$. Po drugie, powrotu od scalonego, idealnego obrazu do chaotycznego, niezbornego Realnego - tego, co wyparte, ulokowane na granicy werbalnej reprezentacji, przejawiające się pod postacią traumy, tak jak wspomniane „rozdarcie czasu”, metafizyczna utrata.

\section{Zakończenie: epizody i epifanie}

Narrator eksponuje rolę „czasu odeszłego, utraconego bezpowrotnie w stopniu wyższym niż w epokach, w których historia nie popada w szaleństwo" $(\mathrm{H}, 7)$. Nie sposób stworzyć koherentnej, uładzonej sagi rodzinnej w stuleciu pieców krematoryjnych, literackie możliwości opisu świata jako całości sensownej i harmonijnej uległy wyczerpaniu - pozostały epizody i okruchy, ale wszak nie da się ,sporządzić portretu człowieka na podstawie odbicia w rozbitym lustrze” (H, 20). Stąd równie istotne co „odnajdywanie czasu” - będące „odnajdywaniem ludzi, lub przynajmniej śladów, jakie po sobie pozostawili”

${ }^{50}$ A. Madaliński, dz. cyt., s. 129.

51 Zob. J. Lacan, Stadium zwierciadta jako czynnik ksztattujacy funkcje Ja w świetle doswiadczenia psychoanalitycznego, tłum. J. Aleksandrowicz, „Psychoterapia” 1987, nr 4, s. 5-9.

52 Por. ,jeśli tylko podmiot został pochwycony w radykalnie zewnętrzną sieć znaczących, jest już martwy, rozczłonkowany, podzielony" - S. Žižek, Wzniosty obiekt ideologii, tłum. J. Bator, P. Dybel, wstęp P. Dybel, Wrocław 2001, s. 206. 
(M, 213) - jest jego konstruowanie ${ }^{53}$. W owym, jak to autor nazywa za Januszem Szuberem, „cerowaniu pamięci” (F, 149) zachodzi coś więcej niż zespalanie rzeczy (na pozór?) izolowanych i rozproszonych. W wypadku nagich świadectw Holokaustu Głowiński optuje za weryzmem i poetyką fragmentu, lecz literaturze przyzwala na produkowanie „tkanki łącznej” 54 . Przeto między rzeczowymi relacjami może pojawić się fikcyjna Krótka historia hochsztaplera Józefa Jelitki nawiązująca do Thomasa Manna, sam narrator może pytać, czy bohaterka istniała naprawdę, albo prosić o pomoc w zaglądaniu do domostw biesa Asmodeusza z Diabta kulawego.

Jaki więc status miałyby reprezentacje Miasteczka w analizowanych opowieściach? W szkicu Świadectwa i style odbioru wśród tych ostatnich znajduje się też odbiór mimetyczny ${ }^{55}$, czyli rozstrzygające mogłoby być nastawienie czytelnika. Z kolei narrator Ktadki... odwołuje się do Williama Faulknera, by usprawiedliwić zamazywanie w swoim Yoknapatawpha granic między fikcją a autentykiem. Wyobrażone uzupełnia usłyszane i pamiętane, lecz sztukowanie pamięci nie osiąga nigdy punktu finalnego - choćby dlatego, że tekst literacki zawsze stanowi synekdochę. W tym przypadku również daje o sobie znać nie-do-opisanie, niebędące brakiem, tylko nadmiarem. W okruchach lustra, odgrzebywanych w trakcie „archeologii codzienności” (H, 223), migocą refleksy, niepokaźne detale - gest, słowo, zastanawiający ubiór czy rytuał - których sensy nie wyczerpują się w obszarze widzialnego/opisywalnego: „Przeszłość nieustannie nas przygniata, żyje w nas i wokół nas krąży, to zatem, co miało być skromną relacją o punktach, drogach i przedmiotach, stało się w sporej mierze czymś całkiem innym" (K, 106). Owe refleksy naturalnie nie wskrzeszą minionego świata ani jego mieszkańców; ich rola polegałaby raczej na tym, że w nagłym przebłysku odsyłają poza „tu i teraz”, a nawet poza „tam i wtedy”. Można by do nich odnieść stwierdzenie Głowińskiego na temat pozornie błahego liryku Wisławy Szymborskiej Ze wspomnień: „Ów epifanijny czas jest czasem momentalnym, chwilą, w której dzieją się wypadki, ale również wiecznością, (...) czasem nie tylko rozległej, długimi trwaniami wypełnionej historii, ale także metafizycznym"56.

53 Warto dodać, że jest ono przez Głowińskiego zaliczane do podstawowych zagadnień narratologicznych - zob. M. Głowiński, Narratologia dzisiaj i nieco dawniej [w:] tegoż, Monolog wewnętrzny Telimeny..., dz. cyt., s. 106 [wyróżn. - K.S.].

${ }^{4}$ Zob. tenże, Kręgi obcości..., dz. cyt., s. 52-53.

55 Zob. tenże, Świadectwa i style odbioru [w:] tegoż, Dzieto wobec odbiorcy..., dz. cyt., s. $147-148$.

56 Tenże, Obrazek z wakacji i wielkie znaczenia. (O wierszu Wistawy Szymborskiej „Ze wspomnieñ”) [w:] tegoż, Monolog wewnętrzny Telimeny..., dz. cyt., s. 367. 


\section{Bibliografia}

Broda M., W cieniu pamięci: byt plac, byt dom, byta topola..., „Kwartalnik Artystyczny" 2003, nr 4.

Browarny W., W kręgu Gtowińskiego, „Odra” 2010, nr 12.

„Czy pan jest nowoczesny?”. Z Michatem Gtowinskim rozmawia Ryszard Koziotek, „Świat i Słowo” 2005.

Głowiński M., „A wszystkiemu sięprzyglądatem”. Oopowiadaniach Janusza Odrową̇̇a-Pieniążka [w:] tegoż, Rozmaitości interpretacyjne. Trzydzieści szkiców, Warszawa 2014.

Głowiński M., Carska filiżanka. Szesnaście opowieści, Warszawa 2016.

Głowiński M., Dzieto wobec odbiorcy. Szkice z komunikacji literackiej, Kraków 1998.

Głowiński M., Elegie autobiograficzne Leśmiana [w:] tegoż, Zaświat przedstawiony. Szkice o poezji Bolestawa Leśmiana, Kraków 1998.

Głowiński M., Fabuty przerwane. Mate szkice 1998-2007, Kraków 2008.

Głowiński M., Historia jednej topoli i inne opowieści, Kraków 2003.

Głowiński M., Ktadka nad czasem. Obrazki z Miasteczka, Kraków 2006.

Głowiński M., Kręgi obcości. Opowieść autobiograficzna, Kraków 2010.

Głowiński M., Labirynt, przestrzeń obcości [w:] tegoż, Mity przebrane. Dionizos Narcyz - Prometeusz - Marchott - labirynt, Kraków 1990.

Głowiński M., Literatura a nos Kleopatry [w:] tegoż, Dzieto wobec odbiorcy. Szkice z komunikacji literackiej, Kraków 1998.

Głowiński M., Literatura wobec symboliki [w:] tegoż, Monolog wewnętrzny Telimeny i inne szkice, Kraków 2007.

Głowiński M., Magdalenka z razowego chleba, Kraków 2001.

Głowiński M., Mate narracje Mirona Biatoszewskiego, „Teksty” 1972, nr 6.

Głowiński M., Mimesis językowa w wypowiedzi literackiej [w:] tegoż, Narracje literackie i nieliterackie, Kraków 1997.

Głowiński M., My z lat trzydziestych. (Rozważania aż nadto subiektywne) [w:] tegoż, Dzień Ulissesa $i$ inne szkice na tematy niemitologiczne, Kraków 2000.

Głowiński M., Narratologia dzisiaj i nieco dawniej [w:] tegoż, Monolog wewnętrzny Telimeny i inne szkice, Kraków 2007.

Głowiński M., Nauka o literaturze wśród innych dyscyplin [w:] tegoż, Monolog wewnętrzny Telimeny i inne szkice, Kraków 2007.

Głowiński M., Nowomowa [w:] Antropologia stowa. Zagadnienia i wybór tekstów, wstęp i red. G. Godlewski, Warszawa 2003.

Głowiński M., O intertekstualności, „Pamiętnik Literacki” 1986, z. 4.

Głowiński M., O powieści w pierwszej osobie [w:] tegoż, Gry powieściowe. Szkice z teorii $i$ historii form narracyjnych, Warszawa 1973.

Głowiński M., Obrazek z wakacji i wielkie znaczenia. (O wierszu Wistawy Szymborskiej „Ze wspomnień”) [w:] tegoż, Monolog wewnętrzny Telimeny i inne szkice, Kraków 2007. 
Głowiński M., Od metod zewnętrznych i wewnętrznych do komunikacji literackiej [w:] tegoż, Dzieto wobec odbiorcy. Szkice z komunikacji literackiej, Kraków 1998.

Głowiński M., Odbiór, konotacje, styl [w:] tegoż, Dzieto wobec odbiorcy. Szkice z komunikacji literackiej, Kraków 1998.

Głowiński M., Poetyka a socjolingwistyka [w:] tegoż, Narracje literackie i nieliterackie, Kraków 1997.

Głowiński M., Polska literatura wspótczesna i paradygmaty symboliczne (1945-1995) [w:] tegoż, Dzień Ulissesa i inne szkice na tematy niemitologiczne, Kraków 2000.

Głowiński M., Powieść jako metodologia powieści [w:] W kregu zagadnień teorii powieści, red. J. Sławiński, Wrocław 1967.

Głowiński M., Przestrzenne tematy $i$ wariacje [w:] tegoż, Dzieto wobec odbiorcy. Szkice z komunikacji literackiej, Kraków 1998.

Głowiński M., „Spotykam go codziennie...”. Bolestawa Leśmiana - trzy kategoryzacje świata [w:] tegoż, Zaświat przedstawiony. Szkice o poezji Bolestawa Leśmiana, Kraków 1998.

Głowiński M., Świadectwa i style odbioru [w:] tegoż, Dzieto wobec odbiorcy. Szkice z komunikacji literackiej, Kraków 1998.

Jakowska K., O narracjach autobiograficznych Michata Gtowinskiego i Andy Rottenberg, „Białostockie Studia Literaturoznawcze” 2010, t. 1.

Kuczyńska-Koschany K., Gtowiński: tożsamość proza (od początku), „Poznańskie Studia Polonistyczne” 2003, Seria Literacka, t. 22.

Lacan J., Stadium zwierciadta jako czynnik ksztattujacy funkcje Ja w świetle doświadczenia psychoanalitycznego, tłum. J. Aleksandrowicz, „Psychoterapia” 1987, nr 4.

[Lektor], Nad Utratą, „Tygodnik Powszechny” 2006, nr 8.

Lewandowski W., Z diabtem po Miasteczku, „Kwartalnik Artystyczny” 2006, nr 2.

Lubas-Bartoszyńska R., Nowsze problemy teoretyczne pisania o sobie. Przyktad wypowiedzi autobiograficznych pisarzy polskich ostatnich dziesięcioleci, „Przestrzenie Teorii” 2006, nr 6.

Madaliński A., Pochwata fikcji, „Twórczość” 2006, nr 10.

Miłosz C., Sens [w:] tegoż, Wiersze, t. 5, Kraków 2009.

Modrzejewska-Świgulska M., Bogusławski M.M., Czy istnieje „profesjonalny” i „nieprofesjonalny” wymiar biografii? Rozważania na kanwie „Opowieści autobiograficznej" Michata Gtowińskiego. Refleksja rozpisana na dwa gtosy [w:] Biografie naukowe. Perspektywa transdyscyplinarna, red. M. Kafar, Łódź 2011.

„Moja ktadka wznoszona nad czasem różne ma wymiary...” - rozmowa z Michatem Gtowińskim, rozm. Ż. Nalewajk, K. Krowiranda, „Tekstualia” 2006, nr 4.

Ricoeur P., Czas i opowieść, t. 1: Intryga i historyczna opowieść, tłum. M. Frankiewicz, Kraków 2008.

Ubertowska A., „Kręgi obcości”, podwójne wyjście. Projekt autobiograficzny Michata Gtowińskiego, „Teksty Drugie” 2011, nr 4.

Žižek S., Wzniosty obiekt ideologii, tłum. J. Bator, P. Dybel, wstęp P. Dybel, Wroctaw 2001. 